\title{
The reproductive biology and cycle of Rioraja agassizi (Müller and Henle, 1841) (Chondrichthyes: Rajidae) in southeastern Brazil, SW Atlantic Ocean
}

\author{
MARÍA CRISTINA ODDONE ${ }^{1}$, ALBERTO F. AMORIM ${ }^{2}$, \\ PATRICIA L. MANCINI ${ }^{3}$, WALTER NORBIS ${ }^{4}$ and GONZALO VELASCO ${ }^{1}$ \\ ${ }^{1}$ Universidade Estadual Paulista, Departamento de Ecologia, Campus Rio Claro Av. 24-A 1515, CP: 199, CEP: 13506- \\ 900, Rio Claro, SP, Brazil. E-mail: mcoddone@rc.unesp.br \\ 2 Instituto de Pesca, Av. Bartolomeu de Gusmão, 192, Ponta da Praia, CEP: 11030-906, Santos, SP, Brazil. \\ ${ }^{3}$ Projeto Albatroz. Av. Rei Alberto I, N. 450, sala 5, Ponta da Praia, CEP: 11030-906, Santos, SP, Brazil. \\ ${ }_{4}^{4}$ Dirección Nacional de Recursos Acuáticos, Departamento de Biología Pesquera, Constituyente 1497, C.P: 11200- \\ P.O. Box 1612, Montevideo, 11200, Uruguay.
}

\begin{abstract}
SUMMARY: Specimens of Rioraja agassizi were collected at Guarujá pier, São Paulo State, Brazil, from March 2005 to March 2006. A total of 275 males were captured. Based on the analysis of the clasper length, gonad weight, clasper gland length, alar thorns and lobule diameter, the size-at-maturity was estimated to be $32 \mathrm{~cm}$. There were 1049 females in the record. Size-at-maturity was calculated in $40 \mathrm{~cm}$. Sexual resting females were observed. Gonadosomatic and hepatosomatic indexes varied significantly in both sexes throughout the year. However, ovulation, egg-laying and presence of sperm in the seminal vesicle were observed all year round. For this reason, an annual cycle with at least one peak in the sexual activity is proposed for this species.
\end{abstract}

Keywords: clasper, clasper gland, vitellogenic follicles, elasmobranchs, nidamental gland, egg-bearing, gonads.

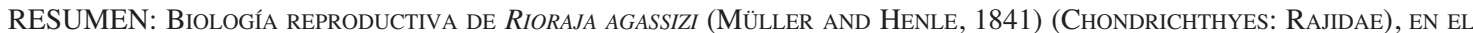
SUdESTE BRASILEÑo, AtLÁntico SudocCidental. - Se colectaron especímenes de Rioraja agassizi en el puerto de Guarujá, Estado de San Pablo, Brasil, desde marzo de 2005 hasta marzo de 2006. Se capturó un número total de 275 machos. De acuerdo con el análisis de la longitud del clasper y de la glándula del clasper, el peso de las gónadas, el diámetro de los lóbulos y el número de espinas alares, el tamaño de primera madurez sexual fue estimado en $32 \mathrm{~cm}$. Se capturó un número de 1049 hembras. El tamaño de primera madurez sexual fue calculado en $40 \mathrm{~cm}$. Se observó reposo sexual en hembras de esta especie. Los índices gonadosomáticos y hepatosomáticos variaron significativamente en ambos sexos a lo largo del año. Sin embargo, la ovulación y la deposición de cápsulas ovígeras sucedieron continuamente durante todo el año, así como la presencia de esperma en la vesícula seminal en ejemplares adultos. Por este motivo, se propone para esta especie, un ciclo reproductivo anual, con por lo menos un pico en la actividad sexual.

Palabras clave: clasper, elasmobranquios, glándula nidamentária, deposición de cápsulas ovígeras, gónadas.

\section{INTRODUCTION}

Elasmobranchs (Chondrichthyes) have an evolutionary history of more than 400 million years, sufficient time for them to develop exquisite senses and complex reproductive modes that rival those of the most advanced tetrapods. Oviparity, the probable ancestral condition in elasmobranchs (Carrier et al., 2004), foreshadows the situation common in reptiles and universal in birds (Callard et al., 1988). The family Rajidae is oviparous and lays its egg capsules in the environment, where they develop 
and hatch. Oviparity in skates is single (external) (Musick and Ellis, 2005) and all Rajids have the same general reproductive cycle, in which egg capsules are deposited in pairs with intervals of 0-5 days between successive depositions (Holden et al., 1971). In the wild, there is a peak in egg laying during the summer and spawning occurs throughout the entire year (Clark, 1922).

The Rio skate Rioraja agassizi Whitley, 1939 (Rajidae: Arhynchobatidae) is endemic to the southwestern Atlantic coast of South America (Compagno, 2005) and occurs from coastal waters to depths of up to $130 \mathrm{~m}$ (Figueiredo, 1977). Females deposit egg capsules with mean dimensions of 47x31 mm (Oddone et al., 2006). Apart from the description of the egg capsule, the reproductive biology of $R$. agassizi-i.e. its sexual development, size-at-maturity and cycle-is unknown.

The assessment of chondrichthyan populations requires a quantitative approach to the study of reproductive biology, size-at-maturity being a key parameter to be estimated (Walker, 2005). In addition, over the past thirty years, catches of rajids have increased in the western Atlantic, mainly as a bycatch of target fisheries, but sustainable catch rates are completely unknown (Frisk et al., 2002). Thus, knowledge of the reproductive parameters, in particularly size-at-maturity, is especially important for making decisions on stock management. In southeast Brazil, R. agassizi is discarded as bycatch in most of the fisheries taking place in that area, and in Santos and Guarujá the larger specimens of $R$. agassizi are landed and commercialised for exportation (Casarini, 2006) because of the rapidly expanding markets for skate wing. When life history characteristics are coupled with the selective removal of large individuals of a given population subjected to intense fishery pressure, a population may become highly susceptible to overexploitation and even disappearance (Brander, 1981; Hoenig and Gruber, 1990; Casey and Myers, 1998). The aims of this work were to describe the sexual development of males and females of $R$. agassizi, to estimate its size-at-maturity and to analyse the trend of the reproductive variables for this species on an annual basis in southeastern Brazil.

\section{MATERIALS AND METHODS}

Specimens of Rioraja agassizi were collected monthly from commercial fishing landings at Guarujá, São Paulo State, Brazil, from March 2005 to March 2006. A total of eight fishing vessels took part in the survey, bringing samples of this species regularly (once or twice a month). The study area is

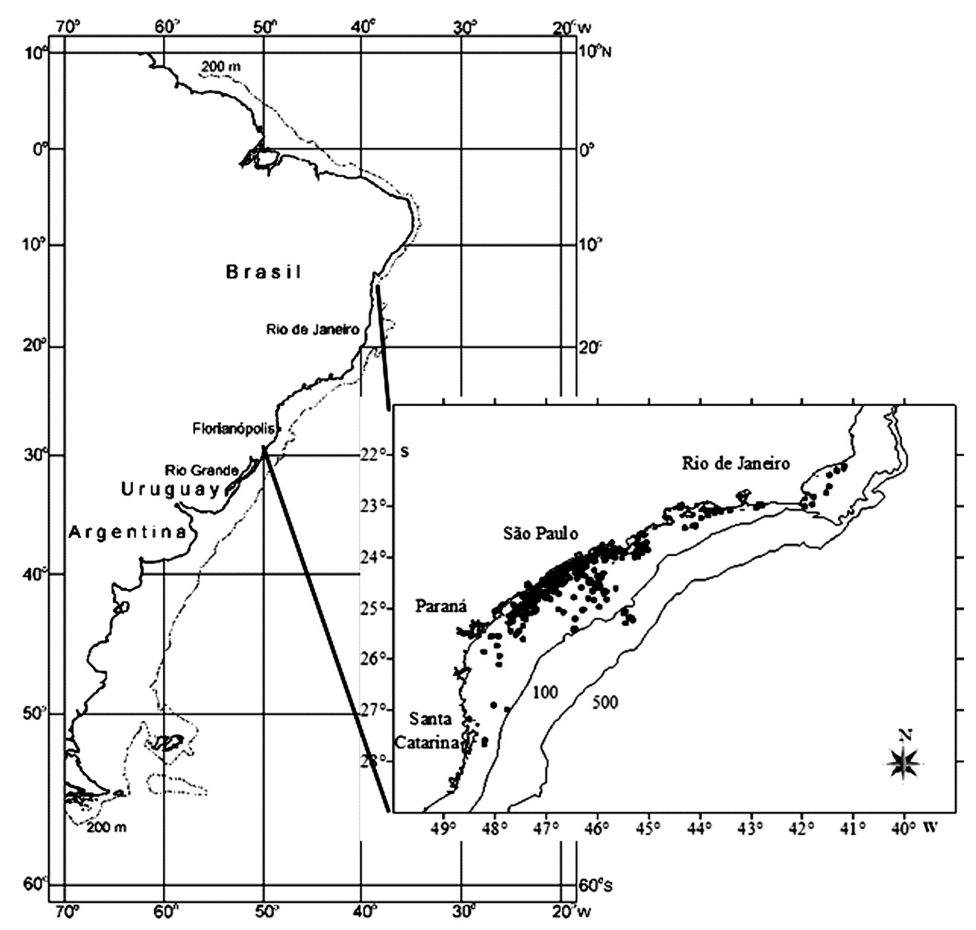

FIG. 1. - Map of the southeastern coast of Brazil showing the study area. Symbols represent the fishing hauls where specimens of Rioraja agassizi were captured. 
situated between latitudes $23^{\circ} 37^{\prime} \mathrm{S}$ and $27^{\circ} 40^{\prime} \mathrm{S}$, at depths of between 10 and 146 m (Fig. 1).

Specimens were measured to the nearest millimetre below as total length (TL) and weighed as total $\left(\mathrm{M}_{\mathrm{T}}\right)$ and gutted $\left(\mathrm{M}_{\mathrm{G}}\right)$ mass $(\mathrm{g})$. Gonad weight $(\mathrm{GW}, \mathrm{g})$ was recorded in both sexes. The electric scales used had 1 and $5 \mathrm{~g}$ precision, and a precision scale was used to weigh material of less than $1 \mathrm{~g}$. Reproductive variables recorded in males were: clasper length $(\mathrm{cm})$, clasper gland length $(\mathrm{cm})$, number of alar thorn rows, number of thorns per row, number of developing thorns (sensu Oddone, 2003), diameter of the largest testicular lobules $(\mathrm{cm})$, and testis weight (g). Clasper length was measured sensu Compagno (1984) and calcification was recorded manually, with the claspers being classified as 'rigid' or flexible' for maturity assessment. Finally, the presence of sperm in the seminal vesicle was noted. In females the variables recorded were: nidamental gland and uterus width $(\mathrm{cm})$, diameter $(\mathrm{cm})$ and colour of the largest ovarian follicle $(\mathrm{cm})$, number of vitellogenic follicles of the 'maturing group' (Fitz and Daiber, 1963), and presence of egg capsules in the uteri (egg-bearing females) or cloaca. Volume (ml) of the largest ovarian follicle and of the ovulated encapsulated oocyte was measured in some specimens to estimate the ovulation size of the follicles. Liver weight $(\mathrm{g})$ was also recorded in both sexes. Specimens were grouped according to the above-mentioned variables and maturity stages were described for R. agassizi, following Walker (2005) (Table 1).

Gonadosomatic and hepatosomatic indexes were calculated as: $\mathrm{GSI}=\left(\mathrm{GW} / \mathrm{M}_{\mathrm{G}}\right) * 100$ and $\mathrm{HSI}=$ $\left(\mathrm{LW} / \mathrm{M}_{\mathrm{G}}\right) * 100$, respectively. A logistic curve was fitted to the relationship between the fraction of mature males or females as a function of TL: $\mathrm{P}_{\mathrm{TL}}=1 /\left(1-\mathrm{e}^{(\mathrm{a}+\mathrm{bTL})}\right)$, where $\mathrm{P}_{\mathrm{TL}}$ is the fraction of mature individuals in length class TL, and $\mathrm{a}$ and $\mathrm{b}$ are the model parameters. With this model, mean size at first maturity, $\mathrm{TL}_{50}$, was estimated by a/b, which represents the body size at which $50 \%$ of the fish are mature (Restrepo and Watson, 1991).

To use parametric/non-parametric tests, normality and homogeneity of variance of the variables were tested by Lilliefors and Levene's tests, respectively. Parametric comparisons were performed using a Student's t-test. Comparisons among monthly HIS, GSI and largest follicle/lobule diameter, were performed using Kruskal-Wallis H-test and post-hoc Mann-Whitney U-test, Bonferroni corrected (Sokal and Rohlf, 1995). As the monthly sample

TABLE 1. - Reproductive stages assumed for males and females of Rioraja agassizi, based on the observation and description of the reproductive organs.

\begin{tabular}{|c|c|c|c|}
\hline Organ & Index & Description & Maturity assumption \\
\hline \multicolumn{4}{|l|}{ FEMALE } \\
\hline \multirow[t]{3}{*}{ Ovary } & $\mathrm{O}=1$ & $1 \mathrm{~mm}$ diameter white follicles & Immature \\
\hline & $\mathrm{O}=2$ & Vitellogenic follicles $<2.0 \mathrm{~cm}$ & Juvenile \\
\hline & $\mathrm{O}=\overline{3}$ & Mature vitellogenic follicles $>=2.0 \mathrm{~cm}$ & Mature \\
\hline \multicolumn{4}{|l|}{ Nidamental } \\
\hline \multirow[t]{3}{*}{ Gland } & $\mathrm{N}=1$ & Indistinct from anterior oviduct & Immature \\
\hline & $\mathrm{N}=2$ & Distinct but only partially formed & Juvenile \\
\hline & $\mathrm{N}=3$ & Fully formed & Mature \\
\hline \multirow[t]{3}{*}{ Uterus } & $\mathrm{U}=1$ & Uniform, thin tubular structure & Immature \\
\hline & $\mathrm{U}=2$ & Ribbon-like structure, wider than $\mathrm{U}=1$, particularly at the anterior end & Juvenile \\
\hline & $\mathrm{U}=3$ & Egg-bearing or distended and vascularised & Mature \\
\hline \multicolumn{4}{|c|}{$-\infty 0$ - } \\
\hline \multirow[t]{3}{*}{ Testicles } & $\mathrm{T}=1$ & Thin tissue strip with epigonal organ predominating & Immature \\
\hline & $\mathrm{T}=2$ & Lobules differentiated, epigonal organ still extensive & Juvenile \\
\hline & $\mathrm{T}=3$ & Lobular zone predominating & Mature \\
\hline \multirow[t]{3}{*}{ Clasper gland } & $\mathrm{S}=1$ & Undifferentiated from surrounding tissue & Immature \\
\hline & $\mathrm{S}=2$ & Easier to differentiate and measure, white-transparent & Juvenile \\
\hline & $\mathrm{S}=3$ & Completely differentiated and developed, light yellow & Mature \\
\hline \multirow[t]{3}{*}{ Alar thorns } & $A=1$ & Absent & Immature \\
\hline & $\mathrm{A}=2$ & Developing & Juvenile \\
\hline & $A=3$ & Fully developed & Mature \\
\hline \multirow[t]{3}{*}{ Clasper } & $\mathrm{C}=1$ & With no calcification, no longer than pelvic fin & Immature \\
\hline & $\mathrm{C}=2$ & Partly calcified, longer than pelvic fin & Juvenile \\
\hline & $\mathrm{C}=\overline{3}$ & Fully calcified, rigid & Mature \\
\hline \multirow[t]{4}{*}{ Seminal vesicle } & $\mathrm{V}=1$ & Sperm absent & Immature \\
\hline & $\mathrm{V}=2$ & Sperm absent & Juvenile \\
\hline & $\mathrm{V}=3$ & Sperm absent, no mating activity & Mature \\
\hline & $\mathrm{V}=4$ & Sperm present, mating activity & Mature \\
\hline
\end{tabular}


size of egg-bearing females and mature females was small and unequal, the application of a statistical test was not possible. Therefore, to compare the percentage of egg-bearing females per month, the standard error of the proportion (percentage) estimate was calculated and corrected by the sample fraction, because of the unequal population and sample size for estimating the monthly proportion of egg-bearing females (Cochran, 1977), as: $q=$ proportion of egg-bearing females $(n)$, relative to the total of mature females $(N)$ for a given month; q=1-p; $\mathrm{CF}=$ correction factor (unequal sample size) calculated as squared root of $(1-\mathrm{f}) ; \mathrm{f}=n / N ; \mathrm{sp}=$ standard error of the percentage or percentage standard deviation; $\mathrm{p}$-sp=calculated percentage minus standard deviation; $\mathrm{p}+\mathrm{sp}=\mathrm{calculated}$ percentage plus standard deviation. The significance level considered in all cases was 0.05 .

\section{RESULTS}

\section{Sexual development of males}

A total of 275 males were captured and analysed. All individuals with TL of up to $32 \mathrm{~cm}$ had uncalcified claspers (immature), but from this size onward specimens with calcified claspers (mature) began to alternate with those with uncalcified ones. The smallest male with a calcified clasper was $33 \mathrm{~cm}$ long, while the largest male with an uncalcified clasper was $36.8 \mathrm{~cm}$ long, and from this size onward all males had calcified claspers. Clasper size varied between 0.45 (neonate specimen) and $2.3 \mathrm{~cm}$ (mean=1.3, SD=0.7, $\mathrm{n}=5)$ in immature males; 4.1 and $6.4 \mathrm{~cm}$ (mean=4.9, $\mathrm{SD}=0.9, \mathrm{n}=7$ ) in juvenile males; and 6.5 and 11.1 (mean=8.5, $\mathrm{SD}=0.8, \mathrm{n}=262$ ) in mature males. The inflexion point of the logistic curve applied to the clasper length/TL ratio was $31.3 \mathrm{~cm} \quad(\mathrm{R}=0.82$, $\mathrm{n}=274$ ) (Fig. 2A). In immature males of $\mathrm{TL}<30 \mathrm{~cm}$, the clasper gland was undeveloped, beginning to appear from TL of $30 \mathrm{~cm}$ onward, and although light in coloration, it was difficult to distinguish from the adjacent pelvic tissue. In specimens larger than $30 \mathrm{~cm}$ long, the gland grew relatively fast to TL, describing a sigmoid curve with a rapid growth phase (juvenile) and continuing to grow slowly from $\mathrm{TL}=34 \mathrm{~cm}$ with high variability in its length. The inflexion point was estimated at 31.6 $\mathrm{cm}(\mathrm{R}=0.68, \mathrm{n}=241)$ (Fig. 2B).
Both testis were functional and no significant difference was detected between mean weight of the right and left one $(\mathrm{t}=1.51 ; \mathrm{df}=46 ; \mathrm{p}=0.1384)$. Testis weight varied between 0.3 and $6.6 \mathrm{~g}$ (Fig. 2C). Testicular lobules started to develop at TL of $31 \mathrm{~cm}$ and lobule diameter varied between 1.2 and $3.7 \mathrm{~mm}$ (mean=2.7; $\mathrm{SD}=0.7, \mathrm{n}=17$ ) for TL between 31 and $35 \mathrm{~cm}$. At TL of $36-40 \mathrm{~cm}$, lobule diameter varied between 0.3 and $0.8 \mathrm{~cm}$ (mean=0.51; SD=0.077, $\mathrm{n}=148$ ) and for TL of $40 \mathrm{~cm}$ onward between 0.4 and 0.8 (mean=0.56; $\mathrm{SD}=0.090, \mathrm{n}=54$ ) (Fig. 2D).

The number of alar thorn rows varied from 1 to 5 on the right and from 1 to 4 on the left pectoral fin, and the difference between means (mean $=2.1$, $\mathrm{SD}=0.7, \mathrm{n}=205$; mean=2.1, $\mathrm{SD}=0.7, \mathrm{n}=204$, respectively) was not significant $(\mathrm{t}=0.39$, g.l $=202$, $\mathrm{p}=0.6959)$. The number of alar thorns per fin varied from 10 to 60 on the right pectoral fin and from 2 to 59 on the left one (mean=29.8, $\mathrm{SD}=10.1, \mathrm{n}=203$; mean=29.5, $\mathrm{SD}=10.9, \mathrm{n}=202$, respectively). There was no significant difference between the number of alar thorns on the right and left pectoral fin $(\mathrm{t}=0.64$, g.l.=201, $\mathrm{p}=0.5230$ ). The number of developing thorns varied from 1 to 12 on the right pelvic fin and from 3 to 15 on the left one (mean=5.8, $\mathrm{SD}=4.5, \mathrm{n}=6$; mean $=8.5, \mathrm{SD}=, \mathrm{n}=4$, respectively), with no significant difference between mean values $(\mathrm{t}=-1.26$, d.f. $=3, p=0.2967)$. Alar thorns were not developed (immature specimens) until $\mathrm{TL}=32 \mathrm{~cm}$, and only at $\mathrm{TL}=33-39$ (juvenile specimens) did the thorns begin to appear. Fully formed alar thorns occurred from TL of $36.5 \mathrm{~cm}$ onward (adults) (Fig. 2E).

According to the analysis of the variables above, males were classified as immature/mature and the maturity curve was applied to the proportion of mature individuals versus TL class (Fig. $2 \mathrm{~F})$, resulting in the $\mathrm{TL}_{50}$ of $32.3 \mathrm{~cm}(\mathrm{R}=0.92$, $\mathrm{n}=35$ ), which corresponds to $68 \%$ of the maximum TL observed. Maturity stages described for male $R$. agassizi are presented in Table 1. Adult males with sperm in the reproductive tract were observed throughout the year.

\section{Sexual development of the females}

A total of 1049 females were analysed. Gonads grew with TL in two phases (Fig. 2G). First, gonad weight increased slowly with TL, with values of 0.1 $0.5 \mathrm{~g}$, in females with white, non-vitellogenic follicles in the ovaries. At TL=32.4 cm, juvenile females with follicles starting vitellogenesis began to occur. 

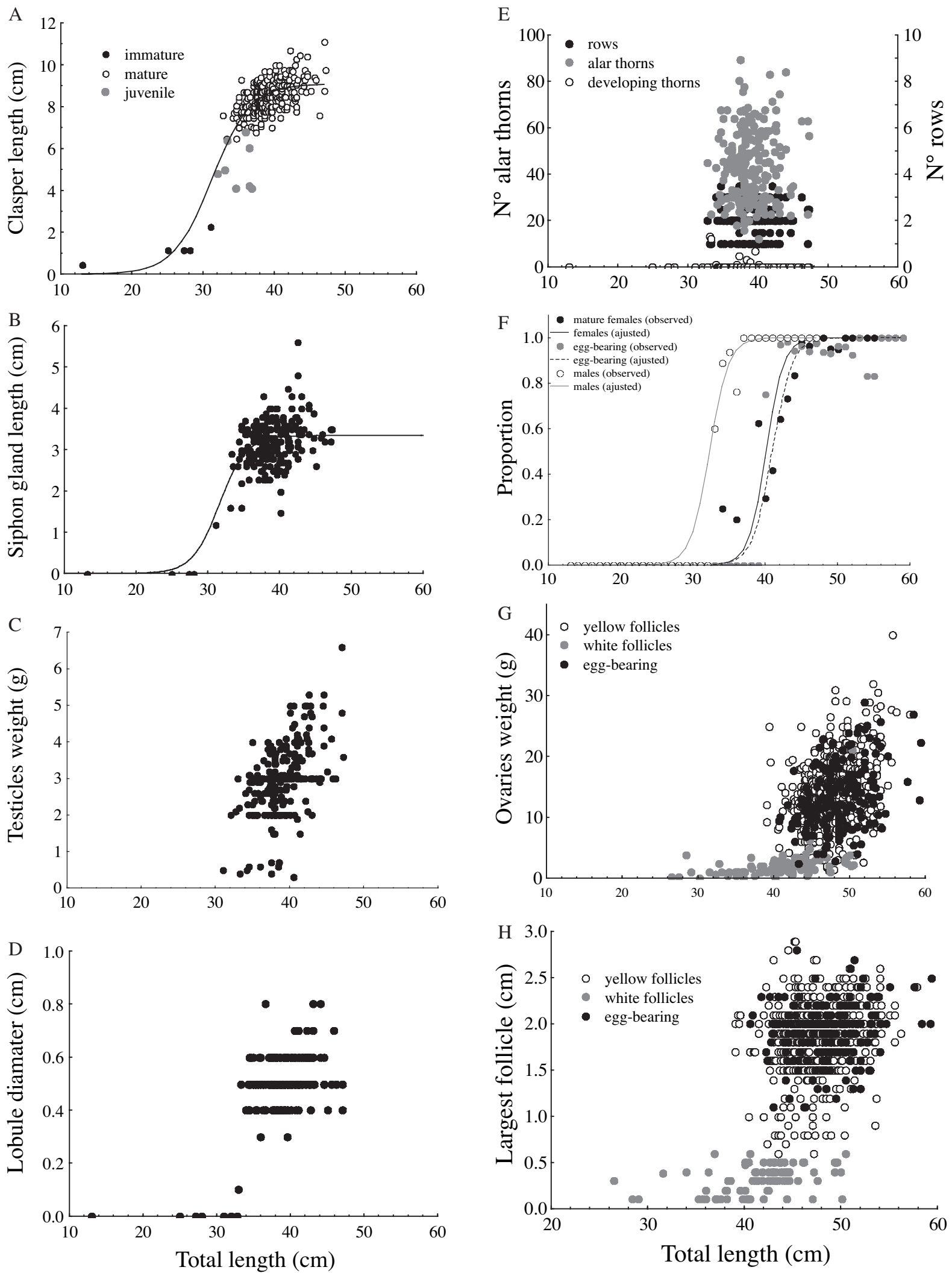

FIG. 2. - Rioraja agassizi. Relationship between total length $(\mathrm{cm})$ and $($ A) clasper length $(\mathrm{cm})$ in immature, juvenile and mature fish; B, clasper gland length $(\mathrm{cm})$ with the logistic curve adjusted; C, testis weight $(\mathrm{g})$; D , lobule diameter $(\mathrm{mm})$; E, number of fully formed alar thorns; developing alar thorns (left y-axis); and number of rows of alar thorns (right y-axis); F, proportion of maturity for males and females and relationship between egg-bearing females and total length $(\mathrm{cm}) ; \mathrm{G}$, ovary weight $(\mathrm{g})$ and total length $(\mathrm{cm}) ; \mathrm{H}$, largest follicle diameter $(\mathrm{cm})$. 

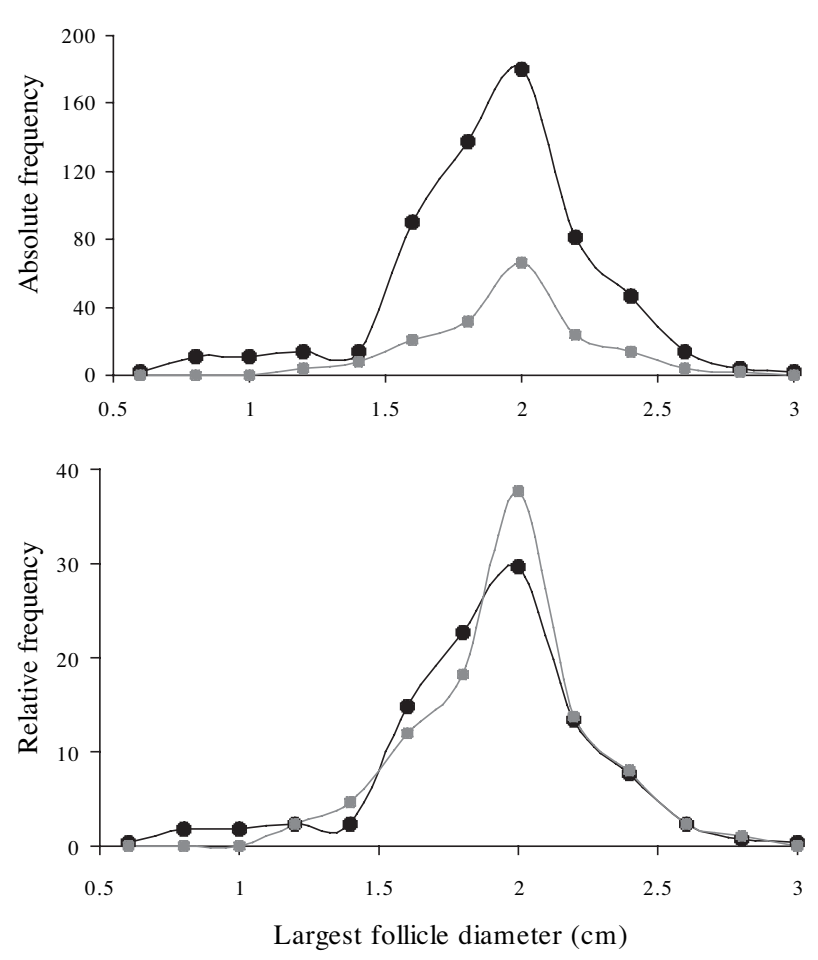

FIG. 3. - Rioraja agassizi. Absolute and relative frequency of follicle size $(\mathrm{cm})$

However, in Figure $2 \mathrm{H}$ such females are still considered as immature with white follicles because these follicles were not yet mature. At $\mathrm{TL}=39.0 \mathrm{~cm}$, an abrupt growth of the gonad weight with TL began because of the occurrence of the first females with maturing vitellogenic follicles, which represents the onset of vitellogenesis. Females with vitellogenic follicles as well as egg-bearing individuals occurred from $\mathrm{TL}=41.0 \mathrm{~cm}$ onwards. Gonad weight in immature females with white follicles varied between 0.1 and $6.3 \mathrm{~g}$ (mean=1.9, $\mathrm{SD}=1.2, \mathrm{n}=109)$, in females with yellow follicles it varied between 1.2 and $40 \mathrm{~g}$ (mean=14.4, $\mathrm{SD}=5.3, \mathrm{n}=586$ ), and in egg-bearing females it varied between 2 and $29 \mathrm{~g}$ (mean=13.5, $\mathrm{SD}=5.2, \mathrm{n}=177$ ). At $\mathrm{TL}=41 \mathrm{~cm}, 50 \%$ of the females classified as mature were egg-bearing, and from $\mathrm{TL}=47 \mathrm{~cm}$ onward $100 \%$ of the females were eggbearing (Fig. 2F, $\mathrm{R}=0.74, \mathrm{n}=58$ ).

White follicles with sizes of $0.1-0.6 \mathrm{~mm}$ (mean=0.3, $\mathrm{SD}=0.15, \mathrm{n}=87$ ) occurred in females of up to $\mathrm{TL}=50.5$. Vitellogenesis began when the follicles reached a diameter of $0.6 \mathrm{~cm}$, and the smallest female with vitellogenic follicles was $40.5 \mathrm{~cm}$ long. Vitellogenic follicle diameter varied between 0.6 and $2.9 \mathrm{~cm}$ (mean=1.8; $\mathrm{SD}=0.35, \mathrm{n}=608$ ). In eggbearing females, vitellogenic follicles had diameters of 1.1-2.8 cm (mean=1.9; $\mathrm{SD}=0.30 ; \mathrm{n}=175)$ (Fig. 3), with vitellogenesis and ovulation occurring in $100 \%$ of these females.

The modal value of the largest vitellogenic follicle in adult females was $2.0 \mathrm{~cm}$. These follicles were more frequent in egg-bearing $(38 \%)$ than in nonegg-bearing mature females (30\%). As ovulation in egg-bearing females occurs immediately after egglaying, it was assumed that follicles with diameters $\geq 2.0 \mathrm{~cm}$ were preovulatory. Relative frequency of these follicles was higher in egg-bearing than in non-egg-bearing females (Fig. 3). The volume of the largest follicle varied between 1.3 and $3.0 \mathrm{ml}$ (mean=2.2, SD=0.53, $\mathrm{n}=10$ ), and the size of the fertilised ovule inside the egg capsule varied between 1.5 and $3.5 \mathrm{ml}$ (mean=2.7, $\mathrm{SD}=0.60, \mathrm{n}=8)$. Therefore, the volume of the preovulatory follicle was $1.5 \mathrm{ml}$, which corresponds to a follicle diameter of $2.0 \mathrm{~cm}$. Females with egg capsules in formation (about $5-80 \%$ of the egg capsule already formed) had vitellogenic follicles with diameters between 1.6 and $2.2 \mathrm{~cm}$ (mean=1.8; $\mathrm{SD}=0.19, \mathrm{n}=10)$, with a bi-modal value of 1.7 and $1.8 \mathrm{~cm}$. The follicular size in females bearing term egg capsules varied between 1.1 and $2.8 \mathrm{~cm}($ mean=1.9, $\mathrm{SD}=0.30, \mathrm{n}=167)$ with a mode of 1.9 , so they were preovulatory. The difference between the mean size of the two kinds of follicles was not significant $(t=-0.25$, d.f. $=175$, $\mathrm{p}=0.8013$ ). Follicular size in non-egg-bearing adult females varied between 0.8 and $2.9 \mathrm{~cm}$ (mean=1.9, $\mathrm{SD}=0.33, \mathrm{n}=320$ ), with a mode of $2.0 \mathrm{~cm}$.

Uterus width varied highly with TL, with some overlapping among immature females, juvenile females with maturation follicles, adult females with vitellogenic follicles and egg-bearing females. Eggbearing females with term egg capsules reached the largest uterus width values due to the width of the egg capsules (Fig. 4A). In immature females, uterus width varied between $0.1-1.7 \mathrm{~cm}$ (mean $=0.8$, $\mathrm{SD}=0.42, \mathrm{n}=92$ ), while in mature females uterus had a width of $1.5-3.5 \mathrm{~cm}$ (mean=1.55, $\mathrm{SD}=0.57$, $\mathrm{n}=588)$. Uteri of egg-bearing females varied between $0.8-3.8 \mathrm{~cm}$ wide (mean=3.0, $\mathrm{SD}=0.44$, $\mathrm{n}=188$ ), being the size variation due to the presence of females with term egg capsules and females starting to secret capsules.

Nidamental gland width varied between 0.1 and $2.4 \mathrm{~cm}$ in immature females (mean $=1.2, \mathrm{SD}=0.51$, $\mathrm{n}=91), 0.9$ and 3.0 in mature, non-egg-bearing females (mean=2.2, $\mathrm{SD}=0.27, \mathrm{n}=632$ ) and 1.6 and 3.6 in egg-bearing females (mean $=2.3, \mathrm{SD}=0.27$, $\mathrm{n}=190$ ). There was high overlapping in the range of 

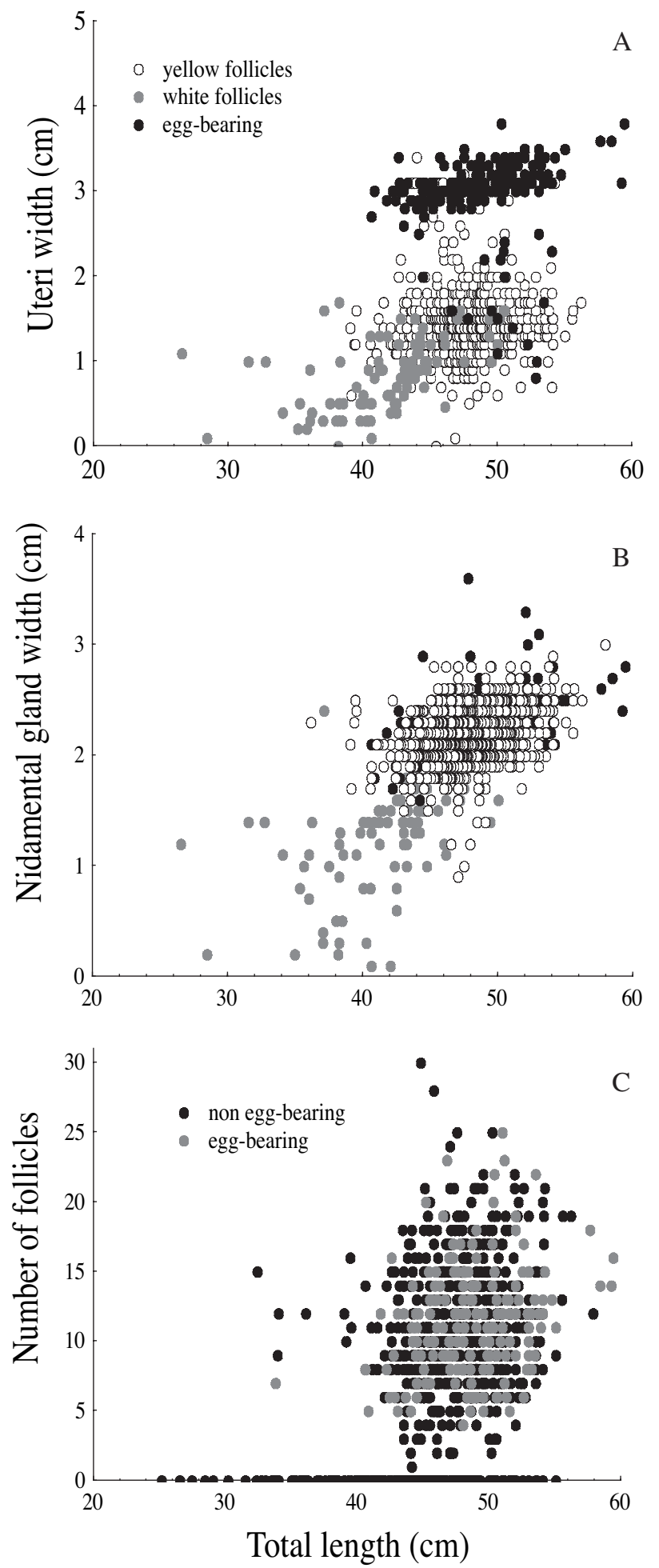

FIG. 4. - Rioraja agassizi. Relationship between total length $(\mathrm{cm})$ and $(A)$ uteri width $(\mathrm{cm}),(B)$ nidamental gland width $(\mathrm{cm})$, and $(\mathrm{C})$ number of mature follicles and total length $(\mathrm{cm})$.

nidamental gland width among immature, juvenile and adult females in relation to TL (Fig. 4B).

The limit between immature-juvenile and juvenile-adult females was evident in the relationships between TL and the largest follicle diameter, and TL and gonad weight. For the remaining variables (between TL/uterus width and TL/nidamental gland width) it was difficult to observe this limit because of the high overlapping among the different developmental stages. Nevertheless, changes in all the reproductive variables with TL, presence/absence of vitellogenesis in ovaries and egg production were used all together as criteria for classifying females as mature or immature. As a result, a $\mathrm{TL}_{50}$ of 40.14 $\mathrm{cm}$ was obtained $(\mathrm{R}=0.84, \mathrm{n}=40$, Fig. $2 \mathrm{~F})$, which corresponds to $68 \%$ of the maximum TL observed.

The number of vitellogenic follicles did not differ significantly between egg-bearing and non-eggbearing females $(t=0.61 ;$ d.f. $=745 ; \mathrm{p}=0.5417)$. In mature, non-egg-bearing females (TL between 40.6 and $57.8 \mathrm{~cm}$ ) the number of vitellogenic follicles varied between 0 and 30 (mean=11.3, $\mathrm{SD}=5.81$, $\mathrm{n}=568$ ) and in egg-bearing females (TL between 40.6 and $59.4 \mathrm{~cm})$ it varied between 4 and 25 (mean=11.4, SD=4.02, n=171) (Fig. 4C). Maturity stages assumed for $R$. agassizi females are presented in Table 1. In a 45.7-cm-long mature female (captured in September), the nidamental gland had secreted $\sim 50 \%$ of the egg capsule and the fertilised oocyte was already encapsulated. One mature female captured in July, with a TL of $47.2 \mathrm{~cm}$, had $\sim 70 \%$ of the egg capsule already formed, and also had encapsulated oocytes.

Sexual resting females were observed in April $(n=3)$, May (4) and November (1). Total lengths of those females were 47.0, 49.4, 49.5, 49.6, 50.0, 50.1, 50.4 and $50.5 \mathrm{~cm}$, respectively, and all of them had developed nidamental glands $>1.6 \mathrm{~cm}$ wide.

\section{Reproductive cycle}

In males, the GSI varied significantly throughout the year $\left(\mathrm{H}_{(12,252)}=46.59, \mathrm{p}=0.0000\right)($ Fig. 5A), as did the HSI $\left(\mathrm{H}_{(12,258)}=56.4 ; \mathrm{p}=0.0000\right)$ (Fig. 5B). Post hoc pairwise comparisons were significant $(\mathrm{p}<0.05)$ between September and the following months: March, May, June, July and August 2005 for both indexes. Testicular lobule diameter varied significantly throughout the year $\left(\mathrm{H}_{(12,229)}=37.16\right.$, $\mathrm{p}=0.0002)$ (Fig. 5C).

In females, the monthly variation of the GSI was also statistically significant $\left(\mathrm{H}_{(12,883)}=76.91\right.$, $\mathrm{p}=0.0000)$, with differences $(\mathrm{p}<0.05)$ between March 2005 and: August, November and February; April and June; June and: August, November and 
600 • M.C. ODDONE et al.
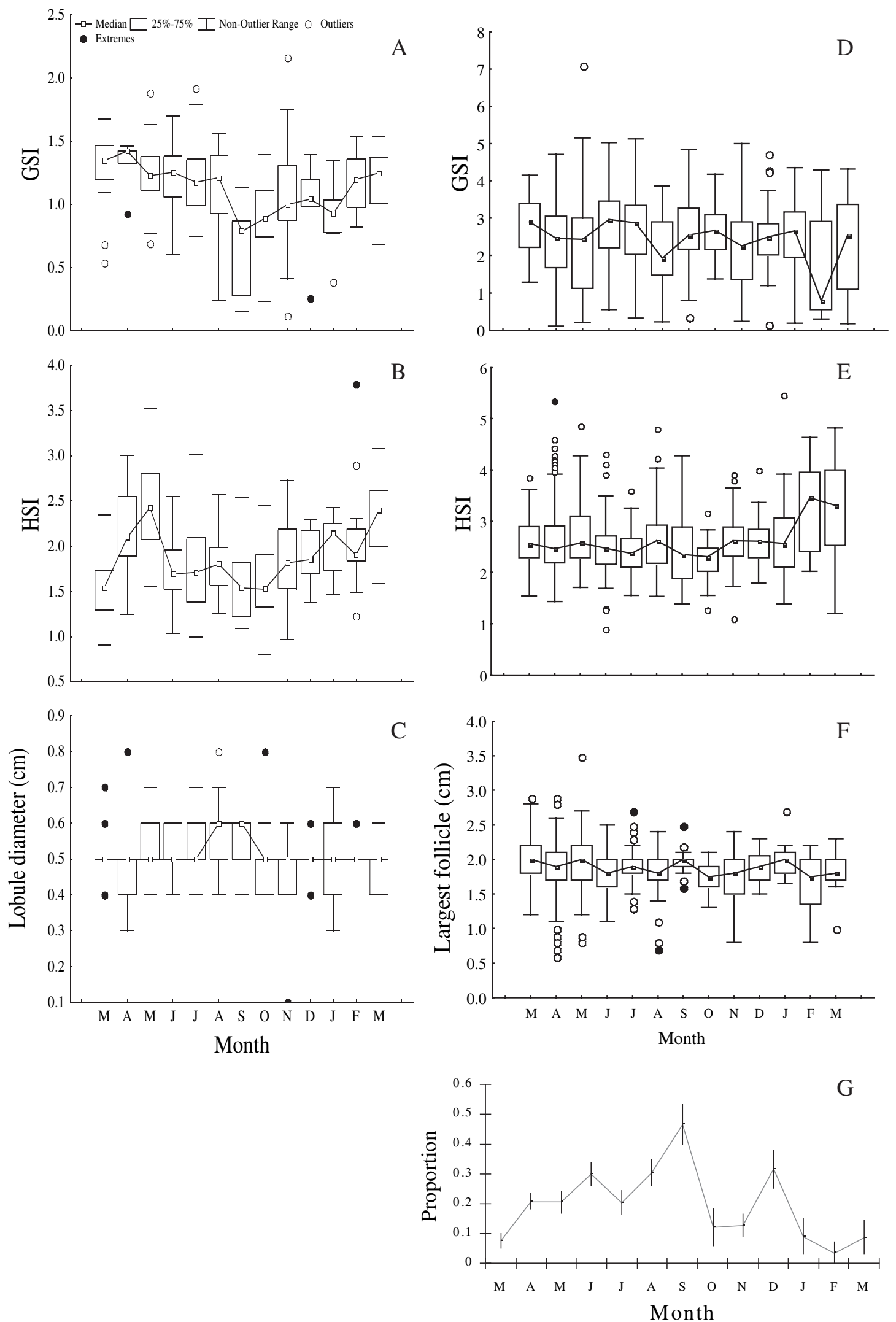

FIG. 5. - Rioraja agassizi. A, monthly gonadosomatic index (GSI) for males; B, monthly hepatosomatic index (HIS) for males, C, monthly lobule diameter (cm) for males; D, monthly gonadosomatic index (GSI) for females; E, monthly hepatosomatic index (HIS) for females; F, monthly largest follicle diameter (cm) for females; G, monthly proportion of egg-bearing females, from March 2005 to March 2006. 
February; July and: February, August; February and: October and December (Fig. 5E). The HSI also varied significantly throughout the year $\left(\mathrm{H}_{(12,955)}=\right.$ 93.37, $\mathrm{p}=0$,0000) (Fig. 5D). Post hoc pairwise comparisons were significant $(\mathrm{p}<0.05)$ between March 2006 and: July and October; and between February 2006 and: June, July, September and October. Females with mature vitellogenic follicles occurred in all months and the mature follicle diameter was observed to vary significantly throughout the year $\left(\mathrm{H}_{(12,790)}=64.64, \mathrm{p}=0.0000\right)$. Post hoc pairwise comparisons showed significant differences $(\mathrm{p}<0.05)$ between: March/2005 and: June, August, October, November and February; November and: September, April and May; September and: June, august and October (Fig. 5F). Egg-bearing females occurred monthly with proportions varying from 0.036 (February) to 0.47 (September) (Fig. 5G).

\section{DISCUSSION}

Gonad symmetry and functionality is common in Rajidae (Teshima and Tomonaga, 1986; Ponz Louro, 1995; Braccini and Chiaramonte, 2002; Oddone and Vooren, 2005). De Queiroz (1986), however, detected differences between ovaries (weight) in Sympterygia acuta and S. bonapartii. Sexual dimorphism is reflected in size-at-maturity, which is common for most elasmobranch species, including rajids. Cortés (2000) reported differences between males and females in traits related to body size, growth and age. He found females reaching maturity at larger sizes than males (bimaturism), and attaining larger maximum sizes and older ages than males, which must be due to the need of females to carry the pups. This investment in growth in favour of reproduction is thus reflected in the delayed onset of maturity in the females. In $R$. agassizi, males and females matured at $68 \%$ of the maximum TL observed. Cortés (2000) noted that elasmobranchs (both sexes) matured at $75 \%$ of their maximum length, and Frisk et al. (2001) noted that dogfishes, skates and rays matured at $73 \%$ of their maximum length. Ebert (2005), however, noted that in some Bathyraja species, males and females attained maturity at the same size.

Ponz Louro (1995) estimated size-at-maturity for $R$. agassizi at $41 \mathrm{~cm}$ for males and $42-44 \mathrm{~cm}$ for females. As this work was carried out in the same area as the present study, it can be observed that in
10 years size-at-maturity may have diminished by several $\mathrm{cm}$, i.e. $4 \mathrm{~cm}$ for males and $1-3 \mathrm{~cm}$ for females. This could be related to the fishing pressure exerted on $R$. agassizi populations in the area.

It was observed that in males sexual development starts at $\mathrm{TL}=31 \mathrm{~cm}$, with the enlargement of the clasper gland and development of the testis (growth in weight and lobule diameter), followed by the development of the alar thorns and the clasper at $\mathrm{TL}=33 \mathrm{~cm}$, and finally sexual maturity at a mean TL of $32 \mathrm{~cm}$. A three-phase sigmoid relationship between clasper length and TL is common in skates (Capapé, 1974; Capapé and Quignard, 1974; Templeman, 1987), the middle phase of the sigmoid representing maturing individuals. Similar relationships have been reported for $S$. bonapartii and $A$. cyclophora (De Queiroz, 1986; Oddone and Velasco, 2004; Oddone and Vooren, 2005). Asimilar pattern in the clasper gland/TL ratio has been recorded for A. cyclophora (Oddone and Vooren, 2005). The alar thorns of Atlantoraja and Rioraja are unique among Rajidae in the way that they are reclined laterally and associated with lateral grooves in the integument (McEachran and Konstantinou, 1996). For A. cyclophora, Oddone and Vooren (2005) recorded up to 6 rows of alar thorns. For $A$. castelnaui and A. platana, Oddone (unpublished data) recorded up to 3 and 5 rows, respectively, while for $R$. agassizi it was recorded a maximum number of 5 rows. A high overlap between mature and immature/juvenile individuals was observed in both sexes of this species, especially regarding testis and number of alar thorns in males, and ovary weight and number of follicles in females. In females, sexual development is first reflected in the enlargement of the nidamental gland ( $36 \mathrm{~cm}$ of TL), followed by an increase in the ovary weight $(\mathrm{TL}=39$ $\mathrm{cm}$ ) and full sexual development at $40 \mathrm{~cm}$ TL. The high variability of the nidamental gland width may be due to the fact that this gland doubles its size after fecundation (Carrier et al., 2004), so for a given TL virgin mature females that have already undergone copulation may occur concurrently and this may be reflected in high gland width variability. There is a difference of $1 \mathrm{~cm}$ between the TL at which $50 \%$ of the females reached size-at-first maturity and the TL at which $50 \%$ of the females were egg-bearing, indicating that reproduction starts immediately after the onset of maturity. The period necessary to achieve this difference in other chondrichthyan species can be several years (Walker, 2005). 
Non-vitellogenic follicles were $0.1-0.5 \mathrm{~cm}$ in diameter in $R$. agassizi, and the onset of vitellogenesis occurred at $0.6 \mathrm{~cm}$ diameter, when the females had a TL of ca. 39. Ponz Louro (1995) observed vitellogenesis for this species in follicles with a diameter of $0.5 \mathrm{~cm}$. Maturation follicle size was 2.0 $\mathrm{cm}$ for this species. In A. cyclophora vitellogenesis starts when the follicles are $0.9 \mathrm{~cm}$ in diameter (Oddone and Vooren, 2005). Follicle maturation size may be species-specific and related to the size of the species, as females of $A$. cyclophora reach a larger TL and mature at $53 \mathrm{~cm}$. In $R$. agassizi, encapsulation took place when $\sim 50 \%$ of the egg capsule had been formed. Templeman (1982) concluded that in Amblyraja radiata, $70 \%$ of the egg capsule was formed before the egg was encapsulated. Oddone (unpublished data) observed that in Atlantoraja platana ovulation takes place when $40-50 \%$ of the egg capsule is already formed. Females undergo a relatively extended immature phase, maturing abruptly after a rather short juvenile phase. Similar patterns were reported by Ebert (2005) and Oddone and Vooren (2005) for other rajids and may reflect a family-specific pattern of maturity. Ponz Louro (1995) did not observe an increase in follicles with TL for $R$. agassizi and reported a total of 18 follicles, in contrast with the 30 follicles of this work. For Holden (1977) the number of mature follicles is determined by the size of the female body cavity. Reproductive cycles of elasmobranchs are complex and, to a large extent, poorly understood (Carrier et $a l ., 2004)$. As in other elasmobranchs, in $R$. agassizi the ovarian cycle (development of vitellogenic follicles until ovulation) occurs in concomitance with gestation (egg capsule development in the uteri in the case of skates). According to the proportion of eggbearing females per month, two peaks in egg laying occurred, the highest in September and a second one in December. Meanwhile, ovulation occurred throughout the year. In Raja pulchra, egg laying also occurs throughout the year except in August and September, peaking from April to June and during November and December (Yeon et al., 1997). Oddone and Vooren (2005) proposed for $A$. cyclophora an annual cycle with continued reproductive activity but with no peaks, or an annual cycle with at least one peak in reproductive activity in spring and/or autumn. Both hypotheses for $A$. cyclophora and the results noted from $R$. pulchra agree with two of the three reproductive cycles proposed for elasmobranchs by Wourms (1977) and may be the case for $R$. agassizi, i.e. continuous reproduction throughout the year with one or two peaks in activity. Walker and Steenbergen (1999) noted that in Amblyraja radiata females with egg capsules were observed throughout the year but with the highest proportion in July-September. Walker and Steenbergen (1999) observed egg-bearing females of Raja asterias throughout the year, and Templeman (1982) observed that 60-70\% of females caught on the NW Canadian coast were egg-bearing, throughout the year. These results lead to the conclusion that in rajids egg-laying is an annual event, and females may lay continuously until senescence or possible resting periods, as demonstrated for R. agassizi and several other species (Holden et al., 1971; Capapé, 1974, 1976; Capapé and Quignard, 1974; Oddone and Vooren, 2005; Ebert, 2005). Sulikowski et al. (2005) observed that in A. radiata a period of enhanced reproductive activity appears to be an integral part of a continuous cycle, although the specific measured parameters and timing of these periods may vary between species. In Raja naevus egg-bearing females only occurred in the third quarter of the year (Walker and Steenbergen, 1999) and in Raja eglanteria the patterns of estradiol concentrations and follicle dynamics suggest a well-defined annual cycle, in which mating and egg deposition take place from December to mid-May (Rasmussen et al., 1999). The male reproductive cycle may also be annual, as indicated by the presence of sperm in the tract throughout the year, suggesting that there is no defined mating period. It is likely that the reduction of activity in September, as suggested by the monthly GSI, indicates a peak in the gonad activity, because it was coupled to a peak in the lobule diameter. The HSI was not clearly opposed to the GSI in males, whereas in females the peak in HIS in February corresponded to the minimum median GSI.

Sexually mature females of Raja erinacea undergo cyclic periods of spawning activity in pairs from 7 to 7 days (Richards et al., 1963). For this species, the period from encapsulation to oviposition takes 3 days (Callard et al., 1988). Analysing follicle diameter and number of follicles, Ponz Louro (1995) concluded that $R$. agassizi is continuously reproducing in the area of Ubatuba, São Paulo littoral, SE Brazil. Ovarian cycle in $S$. acuta and S. bonapartii starts in autumn with a peak in winter and declines in spring and summer, with the highest frequency of egg-bearing females in August (De Queiroz, 1986). Ponz Louro (1995) concludes that high frequency 
values of egg-bearing and reproductively active females as well as immature specimens in virtually all the analysed seasons showed that the area of up to $50 \mathrm{~m}$ depth is an egg-laying and nursery area for this species in Ubatuba.

Even when taken as bycatch, skates are often subjected to high fishing mortality. Some species have been virtually extirpated from large regions (Stevens et al., 2000), and at least nine skate species have disappeared from their distribution range (Brander, 1981; Casey and Myers 1998, Dulvy and Reynolds, 2002). Rioraja agassizi is intensely exploited as a bycatch and only commercialised when the number of the most demanded skates is low. The knowledge of the reproductive parameters and cycle may be of help in management plans for protecting the populations of $R$. agassizi from disappearance. Two anonymous referees who made valuable comments on the submitted manuscript are also thanked.

\section{ACKNOWLEDGEMENTS}

Special thanks to skippers G.A. do Nascimento and P. Silva (CV 'Cigano do Mar' II and III); A. Faria and J. dos Santos (CV 'Antares I' and 'Polares III'); A. de Oliveira Neto (CV Franzese III); O. Vicente (CV 'São Paulo IV'); W. da Silva (CV 'São Paulo II'); E. Nascimento dos Santos (CV 'Dourado e Araguaia'); G. A. do Nascimento (CV 'São Paulo' VI and XI); and J. da Silva (CV 'Jangadeiro XV'). The senior author has a FAPESP (Fundação de Amparo à Pesquisa do Estado de São Paulo, Brazil) $\mathrm{PhD}$ grant which financed this study.

\section{REFERENCES}

Braccini, J.M. and G.E. Chiaramonte. - 2002. Reproductive Biology of Psammobatis extenta. J. Fish. Biol., 61, 272-288.

Brander, K. - 1981. Disappearance of common skate Raia batis from Irish Sea. Nature, 290: 48-49.

Callard, L.P., L. Klosterman and G.V. Callard. - 1988. Reproductive physiology. In: T.J. Shuttleworth (ed.), Physiology of Elasmobranch Fishes, pp. 204-214. Berlin: Springer-Verlag.

Capapé, C. - 1974. Contribution à la biologie des Rajidae des côtes tunisiennes. 2.Raja radula. Arch.Inst. Pasteur Tunis, 51: 211-228.

Capapé, C. - 1976. Contribution à la biologie des Rajidae des côtes tunisiennes. 3. Raja clavata, Linné, 1758: répartition géographique et bathymétrique, sexualité, reproduction, fécondité. Bull. Mus. Nat. His. Nat., 3e Ser., 393: 907-922.

Capapé, C. - 1980. Contribution à la biologie des Rajidae des côtes tunisiennes. 21. Raja asterias, Delaroche, 1809: relations taillepoids, taille-poids du foie, taille-poids des gonades. Coefficients de condition. Rapports hépatosomatique et gona- dosomatique. Bull. Off. Nat. Pêches, 4: 47-65.

Capapé, C., and J.P. Quignard. - 1974. Contribution à la biologie des Rajidae des côtes tunisiennes. 1. Raja miraletus, Linné, 1758: répartition géographique et bathymétrique, sexualité, reproduction, fécondité. Arch. Inst. Pasteur Tunis, 51: 39-60.

Carrier, J.C., H.L.Pratt, and J. Castro. - 2004. Reproductive Biology of Elasmobranchs. In: Carrier, J.C., J. Musick, and M. Heithaus (eds.), Biology of Sharks and Their Relatives, pp 269286. CRC Press, LLC. Boca Raton.

Casarini, L.M. - 2006. Dinâmica populacional de raias demersais do genero Atlantoraja e Rioraja (Elasmobranchii, Rajidae) da costa sudeste e sul do Brasil. Ph. D. thesis, Univ. São Paulo.

Casey, J.M., and R.A. Myers. - 1998. Near extinction of a large, widely distributed fish. Science, 281: 690-691.

Clark, R.S. - 1922. Rays and Skates (Raiae) No. 1: Egg capsules and young. J. Mar. Biol. Assoc. UK, 12: 577-643.

Cochran, W.G. - 1977. Sampling techniques. John Wiley and Sons, New York, N.Y.

Compagno, L.J.V. - 1984. FAO species catalogue. Sharks of the world: an annotated and illustrated catalogue of sharks species known to date. Part 2, Carcharhiniformes. FAO Fish. Syn., 125(4): 251-655.

Compagno, L.J.V. - 2005. Checklist of living chondrichthyes. In: W.C. Hamlett (ed.), Reproductive biology and phylogeny of Chondrichthyes, sharks, batoids and chimaeras, pp. 503-548. Science Publishers, Inc. Enfield (NH), USA.

Cortés, E. - 2000. Life-history patterns and correlations in sharks. Rev. Fish. Sci. 8: 299-344.

De Queiroz, E. - 1986. Estudo comparativo da alimentação de Sympterygia acuta Garman, 1887 e S. bonapartei Müller and Henle, 1841 (Pisces: Rajiformes) com relação à distribuição, abundância, morfologia e reprodução, nas águas litorâneas do Rio Grande do Sul, Brasil. M. Sc. thesis, Fund. Univ. Federal do Rio Grande.

Dulvy, N.K. and J.D. Reynolds. - 2002. Predicting extinction vulnerability in skates. Conserv. Biol., 16: 440-450

Ebert, D.A. - 2005. Reproductive biology of skates, Bathyraja (Ishiyama), along the eastern Bering Sea Continental Slope. $J$. Fish.Biol., 66: 618-649.

Figueiredo, J.L. - 1977. Manual de Peixes Marinhos do Sudeste do Brasil. Introdução, cações, raias e quimeras. Museu de Zoologia da Universidade de São Paulo.

Fitz Jr., E.S. and F.C. Daiber. - 1963. An introduction to the biology of Raja eglanteria Bosc 1802 and Raja erinacea Mitchill 1825 as they occur in Delaware Bay. Bull. Bingham Oceanogr. Coll., 18: 69-97.

Frisk, M.G., T.J. Miller and M.J. Fogarty. - 2001. Estimation and analysis of biological parameters in elasmobranch fishes: A comparative life history study. Can. J. Fish. Aquat. Sci., 58(5): 969-981.

Frisk, M.G., T.J. Miller and M.J. Fogarty. - 2002. The population dynamics of little skate Leucoraja erinacea, winter skate Leucoraja ocellata, and barndoor skate Dipturus laevis: predicting exploitation limits using matrix analyses. ICES J. Mar. Sci., 59: 576-586.

Hoenig, J.M. and S.H. Gruber. - 1990. Life-history patterns in the elasmobranchs: implications for fisheries management. In: Pratt, S.H. Gruber and T. Taniuchi (eds.), Elasmobranchs as living resources: advances in the biology, ecology, systematics, and the status of the fisheries. U.S. Department of Commerce. National Oceanic and Atmospheric Administration Tech. Rep. NMFS, 90: 1-16

Holden, M.J., D.W. Rout and C.N. Humphreys. - 1971. The rate of egg laying by three species of ray. J. Cons. Int. Explor. Mer., 33: 335-339.

Holden, M.J. - 1977. Elasmobranchs. In: G.A. Gulland (ed.), Fish Population Dynamics, pp. 187-215. Wiley, London.

McEachran, J. and H. Konstantinou. - 1996. Survey of the variation in alar and malar thorns in skates: phylogenetic implications (Chondrichthyes: Rajoidei). J. Morph., 228: 165-178.

Musick, J.A. and J.K. Ellis. - 2005. Reproductive evolution of chondrichthyans. In: W. C. Hamlett (ed.), Reproductive biology and phylogeny of chondrichthyes, sharks, batoids and chimaeras, pp 45-71. Science Publishers, Inc. Enfield.

Oddone, M.C. - 2003. Biologia reprodutiva de Atlantoraja cyclophora (Regan, 1903) no Sul do Brasil. Rio Grande. M. Sc. thesis. Fund. Univ. Federal do Rio Grande. 
Oddone, M.C and G. Velasco - 2004. Size at maturity of the smallnose fanskate Sympterygia bonapartii (Müller and Henle, 1841) (Pisces, Elasmobranchii, Rajidae) in the SW Atlantic. ICES J. Mar. Sci., 61(2): 294-297.

Oddone, M.C., A. Mesa and A.F. Amorim. - 2006. The egg capsule of Rioraja agassizi (Müller and Henle, 1841) (Elasmobranchii, Rajidae), endemic to the SW Atlantic. Pan. J. Aquatic Sci., 1(2): 43-48.

Oddone, M.C. and C.M. Vooren. - 2005. Reproductive biology of Atlantoraja cyclophora (Regan 1903) (Elasmobranchii, Rajidae) off southern Brazil. ICES J. Mar. Sci., 62 (6): 1095-1103.

Ponz Louro, M. - 1995. Estratégias e tácticas reprodutivas de elasmobrânquios no ecossistema de Ubatuba, SP, Brasil. M. Sc. thesis, Univ. São Paulo.

Rasmussen L.E.L., D.L. Hess and C.A. Luer. - 1999. Alterations in serum steroid concentrations in the clearnose skate, Raja eglanteria: correlations with season and reproductive status. $J$. Exp. Zool., 284: 575-585.

Restrepo, V.R. and R.A. Watson. - 1991. An approach to modelling crustacean egg-bearing fractions as function of size and season. Can. J. Fish. Aquat. Sci., 48: 1431-1436.

Richards, S.W., D. Merriman and L.H. Calhoun. - 1963. Studies on the marine resources of southern New England. IX. The Biology of the little skate, Raja erinacea Mitchill. Bull. Bingham Oceanogr. Coll., 18: 5-68.

Stevens, J.D., R. Bonfil, N.K. Dulvy and P.A. Walker. - 2002. The effects of fishing on sharks, rays, and chimaeras (Chondrichthyans), and the implications for marine ecosystems. ICES J. Mar. Sci., 57(3): 476-494.

Sokal, R.R. and F.J. Rohlf. - 1995. Biometry, 3rd. ed. W. H. Freeman, San Francisco. Sulikowski, J.A., J. Kneebone, S. Elzey, P. Danley, W.H. Howell and P.W.C Tsang. - 2005. The reproductive cycle of the thorny skate, Amblyraja radiata, in the Gulf of Maine. Fish. Bull., 103: 536-543.

Templeman, W. - 1982. Development, occurrence and characteristics of egg capsules of the thorny skate, Raja radiata, in the Northwest Atlantic. J. Northwest Atl. Fish. Sci., 3: 47-56.

Templeman, W. - 1987. Differences in sexual maturity and related characteristics between populations of thorny skate (Raja radiata) in the northwest Atlantic. J. Northwest Atl. Fish. Sci., 7: 155-167.

Teshima, K. and S. Tomonaga. - 1986. Reproduction of Aleutian Skate, Bathyraja aleutica with Comments on Embryonic Development. Indo-Pacific Fish Biology: Proceedings of the Second International Conference on Indo-Pacific Fishes, edited by T. Uyeno, R. Arai, T. Taniuchi and K. Matsuura, pp 303309, Ichthyological Society of Japan, Tokyo.

Wourms, J.P. - 1977. Reproduction and development in chondrichthyan fishes. Amer. Zool., 17: 379-410.

Walker, P.A. and J.J. van Steenbergen. - 1999. Reproductive effort, cycle and potential of North Sea rays. In: Fleeting Images. Dynamics of North Sea Ray Populations, pp. 93-115. Accumulated papers Ph.D thesis 1999, Univ, van Amsterdam.

Walker, T.I. - 2005. Reproduction in fishery science. In: W.C. Hamlet (ed.), Reproductive biology and phylogeny of chondrichthyans, sharks, batoids and chimaeras, pp 81-127. Science Publishers, Inc. Enfield.

Yeon, I.J., S.H. Hong, Y.C. Park, J.S. Lee, S.T. Kim and H.-K. Cha. - 1997. The reproduction of Raja pulchra Liu in the Yellow Sea. Bull. Nat. Fish. Res. Dev. Inst., 53: 23-36.

Scient. ed.: G. Pequeño.

Received October 18, 2006. Accepted May 17, 2007.

Published online August 3, 2007. 